Cletus D. Kuunifaa

\title{
Sustainability and Reusing Buildings for Libraries: A Review of Selected Documents
}

\begin{abstract}
The reuse of old buildings for new libraries has gained currency within the Library and Information Science (LIS) profession and has informed sustainability initiatives. Adaptive reuse benefits the environment by conserving natural resources and minimizing the need for new materials. This chapter provides a review of some key documents on sustainability, green libraries and the recycling and conversion of buildings as libraries. Building reuse provides an opportunity for sustainable thinking in library planning. Sustainability and going green are already evident in library architecture and design and there is a need to encourage embracing greener practices and adaptive reuse. Sustainability and going green are growth areas for the future. Adaptive reuse and repurposing buildings that have outlived their original purposes for different uses or functions while at the same time retaining their historic features are viable alternatives to new buildings. Building reuse is occurring in developed countries while some developing countries are saddled with challenges slowing adoption of the trend.
\end{abstract}

Keywords: Library buildings - Design and construction; Buildings - Remodelling for other use; Sustainability; Green libraries

\section{Introduction}

Much has been written on adapting older buildings for new use and the approach is no longer an obscure initiative but rather an innovative way forward. It makes sense that with time structures will age and outgrow their usefulness and original functions. With changes in technology and lifestyle, buildings and their design are constantly updated to meet new demands imperative for sustainability.

\section{Methodology}

This literature review and document analysis constitute a qualitative research method to review and evaluate documents in both printed and electronic form (Bowen, 2009) and analyses published journal articles, conference proceedings and books to bring greater understanding of the issue of libraries and sustainability.

2 Open Access. (2021 Cletus D. Kuunifaa, published by De Gruyter. (c) BY-NC-ND This work is licensed under the Creative Commons Attribution-NonCommercial-NoDerivatives 4.0 International License. 
Bowen (2009) stated that like other methods in qualitative research, document analysis requires that data be examined and interpreted to elicit meaning, gain understanding and develop empirical knowledge. The methodology was chosen for this review because it captured and combined many reviewed articles by experts in the field as well as case studies. Reviewing a group of articles on the same topic is a vital means of triangulation.

\section{Sustainability: Definition or Prediction?}

There is much discussion in academia and among researchers on whether sustainability can be defined or predicted. Costanza and Patten (1995) argue that because sustainability can only be assessed after the fact, it is a prediction problem more than a definition problem and they suggest that what passes as definitions of sustainability are therefore often predictions of actions taken today that one hopes will lead to sustainability in the future. As evidenced, a system can only be known to be sustainable after there has been time to observe if the prediction holds true.

Lubin and Esty (2010) argue that sustainability is an emerging megatrend and its course is therefore to some extent predictable as it follows past megatrends like globalization and the rise of the information society. They state that over the past ten years, environmental issues have steadily encroached on businesses' capacity to create value for customers. Environmental issues have been magnified by escalating public and governmental concern about climate change, industrial pollution, food safety, natural resource depletion and some building designs. Consumers in many countries are seeking sustainable products and services or leaning on companies to improve the sustainability of traditional offerings.

\section{What Should Libraries Learn from the Sustainability Megatrend?}

Sustainability is truly relevant to libraries requiring them to adapt and innovate or be relegated to the background. What can libraries learn from emerging ideas about sustainability? Will libraries take advantage of sustainability initiatives and learn to do old things in new ways?

The Talloires Declaration composed and ratified in 1990 marked a watershed in the commitment to environmental sustainability in higher education. Twenty-two 
presidents, rectors and vice- chancellors of universities from all over the world convened at the Tufts European Center in Talloires, France to discuss the role of universities and the role of university presidents in environmental management and sustainable development. A ten-point action plan for incorporating sustainability and environmental literacy in teaching, research, operations and outreach at colleges and universities has been signed by over 500 university leaders in over 50 countries and the Association of University Leaders for a Sustainable Future established (n. d.). The declaration has led to the education of environmentally responsible citizens, fostered environmental literacy for all and incorporated sustainability in the operations of universities. The plan supports an environmentally sustainable future and has informed many. Kurbanoglu and Boustany (2014) contend that the declaration forced academic libraries to start going green.

As ideas for sustainability have been further promoted and extended, sustainable approaches to the design of libraries and other buildings have come to the fore for consideration and implementation. It has become an accepted imperative to create environmentally responsible library facilities and spaces in the $21^{\text {th }}$ century with considerable action undertaken by international and national library associations.

\section{Green Buildings Versus Greening Buildings}

Kurbanoglu and Boustany (2014) identified the difference between green buildings and greening buildings at the European Conference on Information Literacy (ECIL) in Croatia. Green buildings, the authors posit, are structures that are designed, built, renovated, operated or reused in an ecological and resource efficient manner to use finite energy resources prudently to reduce the carbon footprints of buildings. In contrast, the authors point out that greening buildings emphasizes the efficient use of electricity and water, sustainable materials and resources, as well as building materials, furnishings and fixtures with recycled content. Greening buildings makes use of natural and recycled materials and products and emphasizes the installation of geothermal energy systems.

According to the authors, the Arabian Branch of the Scottsdale Public Library in Arizona, the Biblioteca Municipal Publica de Villanueva/Villanueva Public Library in Colombia, the Vennesla bibliotek og kulturhus/Vennesla Library and Culture House in Norway, the Central Public Library in Singapore, the TU Delft/Delft University of Technology Library in the Netherlands, the King Fahad National Library in Riyadh, Saudi Arabia and the Cambridge Public Library in the United States are libraries where green operations and practices, programs and 
services, information systems and collections all reflect the multifaceted concept of green libraries.

\section{The Green Library Movement}

Antonelli has tracked the growth and development of green libraries and the Green Library Movement which has gained enormous support within the library profession (2008). The main concern of the Green Library Movement has been the reduction of libraries' environmental impact. The Green Library Movement grew in popularity and resulted in the building of green libraries, an emphasis on Leadership in Energy and Environmental Design ( LEED) certification while also greening existing library facilities, providing green library services and embracing environmentally supportive and sustainable practices within libraries (Antonelli 2008).

$\mathrm{Al}$ and House (2010) examine the global ethic of the library community in recognizing that reversing the human impact on the environment is part of its social responsibility in the context of the North American library community with attention to policy and practice in five major metropolitan areas. Their findings showed an exciting emergent library discourse on green policy and actions at a local level, but they argued that even though public libraries were implementing green measures at the service and programming levels, they were not yet encoding a green ethic in official institutional language and that library associations were generally remiss in addressing environmental responsibility in their policies. Additional advocacy work on environmental awareness, first at policy level and then, within the community in general would be required to ensure further acceptance of environmental responsibility. Considerable development has taken place since including initiatives sponsored by the International Federation of Library Associations (IFLA) and its support of the United Nations 2030 Agenda for Sustainable Development. The Council of the American Library Association (ALA) in 2019 adopted sustainability as a core value of librarianship after several round table discussions on the subject at conferences. ALA President, Loida Garcia-Febo, indicated that it was a pivotal time for libraries and the communities they serve and that by adding sustainability to its core values, ALA was recognizing that libraries of all types could act as catalysts and inspire future generations to reach solutions that are not only sensible but essential to sustaining life on this planet (American Library Association 2019). 


\title{
Sustainable Library Architecture and Design
}

A sustainable library is defined in the Online Dictionary for Library and Information Science as:

\begin{abstract}
A library designed to minimize negative impact on the natural environment and maximize indoor environmental quality by means of careful site selection, use of natural construction materials and biodegradable products, conservation of resources (water, energy, paper), and responsible waste disposal (recycling, etc.). In new construction and library renovation, sustainability is increasingly achieved through LEED (Leadership in Energy and Environmental Design) certification, a rating system developed and administered by the U.S. Green Building Council (USGBC). Click here to learn more about sustainable libraries. Synonymous with green library (Sustainable library n.d.)
\end{abstract}

Green architecture makes the library green. As noted by Wanda Urbanska (2009, 53), "building a green library may represent the largest public statement any community can make to show its support for sustainability". Any new construction or library renovation requires sustainability to be achieved through Leadership in Energy and Environmental Design (LEED) certification which has become the most accepted standard for environmentally friendly building design in North America and in many other countries throughout the world. Numerous libraries have obtained certification including those already referred to by $\mathrm{Al}$ and House (2010). Similarly, the Building Research Establishment Environmental Assessment Method (BREEAM) is the accepted standard in the United Kingdom and in some other countries around the world according to Rezaallah, Bolognese and Khoraskani (2012). The certification processes promote greening libraries, enhance the image of libraries as proponents of sustainability and assist in advocating for sustainability initiatives in libraries.

Hauke, Latimer and Werner (2013) discuss green libraries and provide ideas and best practice examples on how to green libraries and how and where libraries demonstrate both ingenuity and ethical leadership. The authors cite earlier publications, debates and discussion about the green library movement and the role of libraries and librarians as leaders in the sustainability movement. They posit that library associations and organizations promoted the idea of going green at conferences and sponsored new sustainability round tables at conferences to support the advancement and dissemination of sustainable practices.

They suggest opportunities and models for libraries to implement ecofriendly ventures. Since not all libraries can be rebuilt mostly due to budget constraints, and some because of their historical importance, it is imperative to operate environmentally in existing buildings and without additional resources. It is an exciting time as libraries express their commitment to green values and 
offer open and easy access to information and knowledge about initiatives for appropriate environmental management and sustainable development.

\section{Sustainable Thinking}

It is evident that before sustainability can become a reality, awareness must be created and an appropriate mindset developed, which, according to Aldrich (2018) refers to the alignment of a library's core values and resource allocation with outcomes. Staff time and energy, facilities, collections and technology, must all be aligned with initiatives and activities which reduce environmental impacts and support the local and global community's right to endure and thrive by bringing new and energetic life to fruition through choices made in all areas of library operations and outreach.

The first step towards a sustainable library is sustainable thinking, which is a determined yet realistic attitude that will help libraries spot opportunities for institutional advancement, advocate for and safeguard operating funds, and generate intense loyalty from the communities served (Aldrich 2018). The perspective aligns with the thoughts of Hauke and Werner (2011) who provided answers to questions such as what sustainable means in the context of libraries. What examples are there of projects across the world that have developed sustainable, green libraries? The IFLA Green Library Award sponsored by IFLA's recently established Environmental Sustainability and Libraries Section (ENSULIB) and De Gruyter since 2016 has done much to promote green libraries initiatives and sustainable thinking within libraries. The notion of sustainable thinking not only urges libraries to think differently, with intent, about everything that they do, but demonstrates how to use construction and renovation projects as unique opportunities for positive changes according to Aldrich (2018).

As suggested by Hauke and Werner (2011), libraries as non-commercial public buildings are especially suited to provide examples of sustainability, to distribute and disseminate ideas about sustainability to the community, and to promote civic involvement in sustainability. Being green complements sustainability, and vice versa, and requires libraries to take environmental issues into account when making choices. It also means consuming resources at a rate no faster than they can renew themselves and generating waste at a rate no faster than can be assimilated by the environment (Kurbanoglu and Boustany 2014).

Sustainability represents the foundation of an official plan to continue to guide the growth of institutions and societies at large and quintessentially becomes a conceptual framework for a holistic approach for longevity in institu- 
tions (Kurbanoglu and Boustany 2014). If the focus is on the needs of future generations, sustainability and holistic concepts will be incorporated in the design of work systems and of buildings. Sustainability is clearly a driving force in the design, delivery and operation of all services, including library services. Sustainability and going green are leading to the significance of concepts ranging from biophilia to low energy consumption in the design of library facilities and an emphasis on environmental and economic performance.

\section{Reuse as an Opportunity for Sustainable Thinking}

Hauke and Werner (2011) recommend the reuse of old buildings as an opportunity for sustainable thinking in library planning. The authors advocate the reuse of empty buildings no longer serving their initial functions or purposes. The rehabilitation of such buildings has become a key concern in the implementation of eco-friendly initiatives. The authors observe that for a long time the adaptation of old buildings for library use was rejected and the emphasis was on the benefits of a new building as evidenced by the quote: "A librarian must never accept an old building which has previously been used for other purposes" (Hauke and Werner 2011, 3). However, a debate at the IFLA conference in Budapest in 1985 about what conditions must be fulfilled for an old building to be converted into a library changed the trajectory of the discussion. More light was shed on such discussions by Santi Romero (2007) who indicated the possibilities of reuse and developed a typology of adaptable buildings, setting out the advantages and disadvantages of converting and renovating different building types. ${ }^{1}$

Simply put, the positive aspects of reuse of existing buildings in terms of retaining symbolic value, cultural identity, urban ambience, frequently central location, architectural distinctiveness and heritage, community meaning and relevance and acceptance by the public are expected to reinforce local, regional, national and in some cases international support for sustainability initiatives in library architecture.

The process of rededication of a building with a former different use into a library, and the recycling or reuse of existing buildings into new use will become increasingly necessary in the future. The idea, Hauke and Werner (2011) argue, translates into reducing the ecological footprint of library buildings in a cost-effective and efficient way. They also argue that contrary to earlier misconceptions which posited that projects repurposing buildings into libraries could not become

1 An earlier chapter by Santi Romero in this book expands on his earlier work. 
good libraries, many have been successful. Examples cited by Hauke and Werner are found in Germany, Italy, Austria, Switzerland and the United States.

Sherin (2018) explores how values and sustainability can reshape the way design management is practised and applied. The book discusses how designers can combine innovative creative thinking with analytical problem-solving skills to produce outputs that are business ready and ethically driven. The book is relevant to sustainable library design as it cites numerous international examples showing how ethical design can be utilized effectively. It is a good resource to help design and project managers to use traditional design competencies in visionary ways and enable them to engage with a diverse set of stakeholders to solve universal design problems.

Clark (2008) makes a case for reuse not only in relation to cultural distinction, aesthetics and expense but also notes that adaptive reuse is different from restoration or preservation. He points out that while a restoration or preservation project involves restoring a building to its original state, adaptive reuse changes the intent of a structure to meet the modern user's needs. The fact that the wasteful processes of demolition and reconstruction are bypassed makes adaptive reuse attractive. Environmental benefits combined with energy savings and the social advantage of repurposing a place with valued heritage make adaptive reuse an essential component of sustainable development. It is critical that a library and its patrons and residents make wise use of non-renewable resources and strive to protect, enhance and restore the institution of the library so that future generations will be able to continue to enjoy and use it.

Li and Tsai (2017) show how historic buildings are being recycled into libraries all over the world. They contend that the rededication of a building with a former different use into a library is obviously recycling. The transformation of an existing building with a prior non-library function into a library brings the challenge and the opportunity for sustainable thinking in library planning. Their article demonstrates how adaptive reuse can provide an innovative resolution for buildings no longer in use, even decreasing land use and cost by avoiding demolition and new construction. The proportion of libraries adapted from old buildings when compared to construction of new buildings is likely to remain significant in the future especially in developed parts of the world.

\section{Preservation of Cultural Heritage}

This review notes Given and McTavish's view (2010) which suggests that as cultural institutions begin to share physical and human resources and new tech- 
nologies reshape approaches to access and preservation, educational programs must respond in kind. They refer to the ways in which the current convergence of libraries, archives and museums mark a return to tradition rather than a departure from it and question whether new technologies and curricula are leading the three fields of study and practice into new territory, or whether they represent new stages in an ongoing history of acquisition, documentation, representation and access to the enduring knowledge of the three communities. The views of Given and McTavish reinforce sustainability as it relates to preservation of cultural heritage, historical identity of places and buildings, and preservation of the genius loci (Hauke and Werner 2011).

Historic buildings are being recycled into libraries all over the world with many gaining a new purpose and vigour. Examples occur throughout this book and elsewhere and former buildings include silos, post offices, barracks, breweries, factories, railway stations and stables, all transformed into libraries (Hauke and Werner 2011).

Li and Tsai (2017) examined school buildings in Taiwan. For a historic school building no longer serving in its original capacity, the only alternative to demolition is adaptive reuse. The most successful reuse projects seek to revitalize links to the community and preserve the history of the original connection through a new appropriate function. Otherwise, the perception that historic old school buildings are functionally obsolete is a contributing factor to why they sit empty for so long. It is assumed that buildings wear out and become useless, but in truth they do not wear out, they only deteriorate. Minor building elements may need to be repaired or replaced over time but structural elements such as the ceilings, walls, floors and foundations may never need more than occasional repair.

It is in the best interest of the LIS profession to capitalize on the historic nature of the existing building when considering reuse and to consider the rationale for reuse which must be ultimately sustainable and inherently green.

The Bibliothek Luckenwalde/Bibliothek im Bahnhof/Luckenwalde City Library, Germany, is a transformation of a railway station (Hauke and Werner 2011, 2; Sanne 2009). It operated from the beginning of the $20^{\text {th }}$ century in a small town located half an hour train ride from Berlin. It was an excellent location for a library especially for train travellers and was transformed by ff-architekten Berlin into a beautiful library. However, the existing building did not have sufficient capacity for the required 45,000 volumes and the 50,000 yearly users. In addition to the adaptive reuse of the existing structure, the architects proposed a shimmering golden extension with a children's library on the ground floor and a young adult library on the first floor.

The Library of the Hochschule Luzern/Lucerne University of Applied Sciences and Arts in Switzerland was a former logistic centre for Swiss Mail (Hauke 
and Werner 2011, 2; Schelling 2011) and was repurposed to make use of its excellent location near the main station in the middle of the city with good access to public transport. It cost less than half the costs of a new building of the same size and location with a flexible use of space making the case for reuse viable and efficient.

Adaptive reuse and repurposed historic buildings minimize costs, extend the life of buildings, preserve the existing environment and contribute in a global context to the management of climate change.

\section{Challenges Facing Sustainable Goals in Developing Countries}

It is perhaps surprising that while there is much good news about adaptive reuse, sustainable thinking and greening libraries in developed countries, the same cannot be said about developing countries, especially in Africa. One example is Ghana which lacks a proactive approach to developing and implementing urban policies capable of adjusting to the ever-changing and challenging demography and environment (Rosenberg 2006).

Some libraries in Ghana are facing numerous challenges that threaten their ability to become viable pillars of sustainable development. The buildings are typically unplanned with no drainage or universal access. They are financially fragile, make inefficient use of public services, and are subject to inappropriate building construction which makes them susceptible not only to climate change, but also to severe socio-economic hardship (Rosenberg 2006). Amidst these challenges, sustainability has not caught on despite some countries being signatories to the United Nations Sustainable Development Goals (SDGs) (United Nations 2015) to end poverty and protect the planet and ensure prosperity for all.

It would be appropriate to advocate for such laudable initiatives related to building reuse and sustainable design at sustainability round tables at international and local conferences to identify a new type of building infrastructure that would achieve economic growth through an economic base that does not drain or pollute natural resources, but rather uses recycled products to retain the invested energy. Such initiatives do exist but could be extended. 


\section{Conclusion}

It is a pivotal time for the pursuit of sustainable development in libraries and communities have much to gain from adapting and reusing buildings. The results, the findings and observations in this document analysis provide a strong argument for sustainability. The literature review highlights the wider ongoing dialogue in the field. Sustainability and going green are growth areas for the future of libraries. A rational case is made for adaptive reuse and the repurposing of buildings that have outlived their original purposes for different uses or functions while at the same time retaining their historic features.

While sustainability and going green are trends that have already benefitted library architecture and design in developed countries, the same cannot necessarily be said about developing countries, with Ghana as an example.

In making a case for building reuse, it will be necessary to weigh the cultural importance, aesthetics and costs for any individual project. Often the most important factor in the decision to adapt an existing building is the initial projected cost and budgets play a large part in the discussion and implementation of sustainability initiatives.

\section{References}

Al, Rodney, and Sara House. 2010. "Going Green in North American Public Libraries: A Critical Snapshot of Policy and Practice.” Paper presented at $76^{\text {th }}$ IFLA World Library and Information Congress, Gothenburg, Sweden. https://www.ifla.org/ past-wlic/2010/135-al-en.pdf

Aldrich, Rebekkah Smith. 2018. Sustainable Thinking: Ensuring Your Library Future in an Uncertain World. Chicago: ALA Editions.

American Library Association. 2019. "Sustainability is Now a Core Value of the Library Profession.” ALA News, October 31, 2019. https://sustainablelibrariesinitiative.org/news/ sustainability-now-core-value-library-profession

Antonelli, Monika. 2008. "The Green Library Movement: An Overview of Green Library Literature and Actions from 1979 to the Future of Green Libraries." Electronic Green Journal 1, no. 27. https://escholarship.org/uc/item/39d3v236

Association of University Leaders for a Sustainable Future. [n. d.]. "Talloires Declaration.” http://ulsf.org/talloires-declaration/

Bowen, Glenn A. 2009. “Document Analysis as a Qualitative Research Method.” Qualitative Research Journal 9, no. 2: 27-42. https://doi.org/10.3316/QRJ0902027

Clark, Dave. 2008. “Adapting an Older Building for a New Use.” Buildings, April 1, 2008. https://www.buildings.com/articles/34689/adapting-older-building-new-use 
Costanza, Robert, and Bernard C. Patten. 1995. "Defining and Predicting Sustainability." Ecological Economics 15: 193-96. http://www.robertcostanza.com/wp-content/ uploads/2017/02/1995___CostanzaPatten_DefiningSustainability.pdf

Given, Lisa, and Liane McTavish. 2010. "What's Old is New Again: The Reconvergence of Libraries, Archives, and Museums in the Digital Age." Library Quarterly 80, no. 1: 7-32. https://doi.org/10.1086/648461

Hauke, Petra, and Klaus Ulrich Werner. 2011. "The Secondhand Library Building: Sustainable Thinking Through Recycling Old Buildings into New Libraries." Paper presented at $77^{\text {th }}$ IFLA World Library and Information Congress, San Juan, Puerto Rico. https://www.ifla.org/ past-wlic/2011/196-hauke-en.pdf

Hauke, Petra, and Klaus Ulrich Werner. 2013. “Going Green as a Marketing Tool for Libraries: Environmentally Sustainable Management Practices." Paper presented at $79^{\text {th }}$ IFLA World Library and Information Congress, Singapore. http://library.ifla.org/147/1/086-hauke-en. pdf

Hauke, Petra, Karen Latimer, and Klaus Ulrich Werner. 2013. The Green Library = Die Grüne Bibliothek: The Challenge of Environmental Sustainability. Berlin/Boston: De Gruyter. https://www.ibi.hu-berlin.de/de/studium/studprojekte/buchidee/bi12

Kurbanoglu, Setrap, and Joumana Boustany. 2014. "From Green Libraries to Green Information Literacy." PowerPoint presentation, European Conference on Information Literacy, Dubrovnik, Croatia. October 20-23, 2014. http://ecil2014.ilconf.org/wp-content/ uploads/2014/11/kurbanoglu_boustany.pdf

Li, Hsiang-Wen, and Tsai Tsung-Chieh. 2017. "Adaptive Reuse Strategies for Historic Old School Building in Taiwan: A Case Study of PKVS." International Journal of Organizational Innovation 10, no. 1: 101-09. https://www.ijoi-online.org/attachments/article/53/ Final $\% 20$ lssue $\% 20$ Vol\%2010\%20Num $\% 201 \% 20$ July\%202017\%20Section $\% 20$ B $\% 20$ revised.pdf

Lubin, David A., and Daniel C. Esty. 2010. "The Sustainability Imperative." Harvard Business Review 88, no. 5: 42-50. https://hbr.org/2010/05/the-sustainability-imperative

Rezaallah, Anahita, Cecilia Bolognesi, and Rohan Khoraskani. 2012. "LEED and BREEAM; Comparison between Policies, Assessment Criteria and Calculation Methods." In Proceedings of the $1^{\text {st }}$ International Conference on Building Sustainability Assessment, Porto, Portugal. https://www.researchgate.net/publication/261079555_LEED_and_ BREEAM_Comparison_between_policies_assessment_criteria_and_calculation_methods Romero, Santi. 2007. “Renovating Historic Buildings.” In IFLA Library Building Guidelines: Developments \& Reflections, edited by Karen Latimer and Helen Niegaard, 172-202. München: Saur.

Rosenberg, Diana. 2006. “Towards the Digital Library in Africa." The Electronic Library 24, no. 3: 289-93. https://doi.org/10.1108/02640470610671150

Sanne, Lutz. 2009. "Vom Bahnhof zur Bibliothek: Best Practice in Luckenwalde; Funktionsbeschreibung und Raumprogramm." In Bibliotheken bauen und ausstatten, edited by Petra Hauke and Klaus Ulrich Werner, 114-31. Bad Honnef: Bock + Herchen. https://edoc.hu-berlin.de/handle/18452/2825

Schelling, Tobias. 2011. "Hier ging einmal die Post ab ... Die Zentral- und Hochschulbibliothek Luzern in einem nachgenutzten Industriegebäude." In Secondhand - aber exzellent! Bibliotheken bauen im Bestand, edited by Petra Hauke and Klaus Ulrich Werner, 60-73. Bad Honnef: Bock + Herchen. https://edoc.hu-berlin.de/handle/18452/2919 
Sherin, Aaris. 2018. Sustainable Thinking: Ethical Approaches to Design and Design Management. New York, NY: Fairchild Books.

"Sustainable library." [n. d.]. In Reitz, Joan. ODLIS, Online Dictionary for Library and Information Science. https://www.abc-clio.com/ODLIS/odlis_s.aspx\#sustainablelib

United Nations. 2015. Transforming Our World: The 2030 Agenda for Sustainable Development. [New York: United Nations, Division for Sustainable Development]. https:// sustainabledevelopment.un.org/post2015/transformingourworld

Urbanska, Wanda. 2009. “A Greener Library a Greener You.” American Libraries 40, no. 4: 52-55. https://www.jstor.org/stable/25650271 